\title{
Role of Selective Cyclo-Oxygenase-2 Inhibitor Celecoxib in Canine Osteosarcoma Cell Culture
}

\author{
Paulo R. O. Bersano ${ }^{*}$, Maria T. S. Alves ${ }^{2}$, Maria F. M. R. Gartner ${ }^{3}$, Adriana Camargo Ferrasi ${ }^{4}$, \\ João F. Lima-Neto ${ }^{5}$, Fernanda C. Landim ${ }^{5}$, Stephane C. Vexenat ${ }^{1}$, Carlos Eduardo Fonseca Alves ${ }^{1}$, \\ Glenda Nicioli da Silva ${ }^{2}$, Noeme S. Rocha ${ }^{1}$ \\ ${ }^{1}$ Laboratory of Investigative and Comparative Pathology, School of Veterinary Medicine and Animal Science, Universidade Estadual \\ Paulista, Botucatu, Brazil; ${ }^{2}$ Department of Pathology, Paulista School of Medicine, Federal University of São Paulo, São Paulo, Bra- \\ zil; ${ }^{3}$ Institute of Molecular Pathology and Immunology of University of Porto, Porto, Portugal; ${ }^{4}$ Hemocentro Paulista School of Me- \\ dicine, Federal University of São Paulo, São Paulo, Brazil; ${ }^{5}$ Laboratory of Reproduction and Cellular Therapy, Department of Ani- \\ mal Reproduction and Veterinary Radiology, Universidade Estadual Paulista, Botucatu, Brazil. \\ Email: probersano@yahoo.com.br,mtsalves@unifesp.br, joaoferreiralima@yahoo.com.br, fernanda@fmvz.unesp.br, \\ stephanevexenat@yahoo.com.br, carloseduardofa@hotmail.com,nicioli@fmb.unesp.br, rochanoeme@fmvz.unesp.br
}

Received May $1^{\text {st }}, 2013$; revised June $1^{\text {st }}, 2013$; accepted June $15^{\text {th }}, 2013$

Copyright $(\mathcal{C} 2013$ Paulo R. O. Bersano et al. This is an open access article distributed under the Creative Commons Attribution License, which permits unrestricted use, distribution, and reproduction in any medium, provided the original work is properly cited.

\begin{abstract}
Background: Experimental studies have shown that cyclo-oxygenase-2 (Cox2) is related to the development and progression of tumors, since this enzyme is induced and expressed by cells such as macrophages, osteoblasts, "activated" endothelial cells, and tumor cells. The activity in tumors includes proliferation, cell transformation, tumor growth, invasion and metastasis and may play an important role in carcinogenesis of the canine osteosarcoma, since it has high expression in tissue fragments. The combination of selective Cox 2 inhibitors and other treatment modalities is the basis for a new anti-cancer therapy strategy. This in vitro study exposed primary cells of five different canine osteosarcoma cultures to selective Cox 2 inhibitor at increasing concentrations and times. Results: For Cox 2 negative cultures, despite the absence of differences, greater sensitivity of cells to treatment was observed. For Cox 2 positive cultures, a higher number of necrotic cells were observed $(\mathrm{P} \leq 0.05)$, when compared with negative cultures. For exposure times with Celecoxib doses, no difference $(\mathrm{P}>0.05)$ was found between the three times analyzed for living, apoptotic and apoptotic/necrotic cells. There are similarities in the values of $24 \mathrm{~h}$ and $48 \mathrm{~h}$, with slight reduction of living cells, increasing those undergoing apoptosis and apoptosis/necrosis. There was significance for necrosis $(\mathrm{P} \leq 0.05)$. In 72 hours, a significant difference was observed between the other two previous values $(\mathrm{P} \leq 0.05)$. It was found for the group of 100 $\mu \mathrm{M} \cdot \mathrm{L}^{-1}$, that there was a numerically greater signaling for apoptosis and lower $(\mathrm{P}=0.08)$ for necrosis, and this point was the onset of the pharmacodynamic phenomenon, with drop in the values for living cells and increased number of necrotic cells, with a tendency $(\mathrm{P}=0.08)$ for reducing the percentage of necrotic cells for the group of $100 \mu \mathrm{M} \cdot \mathrm{L}^{-1}$ when compared to that of $10 \mu \mathrm{M} \cdot \mathrm{L}^{-1}$. Conclusions: For Cox2 positive and negative cultures, there was difference for necrotic cells and there was no difference between Cox2 positive and Cox 2 negative groups in relation to the percentage of living cells and apoptotic and apoptotic/necrotic cells. At time of 72 hours, higher percentage of living cells, lower percentage of apoptotic cells and increased percentage of necrotic cells in relation to groups of 24 and 48 hours were observed. A tendency for reducing the percentage of necrotic cells for the group of $100 \mu \mathrm{M} \cdot \mathrm{L}^{-1}$ when compared to that of the group of $10 \mu \mathrm{M} \cdot \mathrm{L}^{-1}$ was observed.
\end{abstract}

Keywords: Canine; Osteosarcoma; Cyclo-Oxygenase-2; Celecoxib

\section{Introduction}

Osteosarcoma (OS) is the primary bone tumor most frequently diagnosed in dogs, accounting for more than $80 \%$ of cases [1-3], representing excellent in vivo model for human OS [4,5], since its biology in dogs is similar [6].
This type of cancer accounts for approximately $2 \%$ to $5 \%$ of all cancers in dogs [7] and less than $1 \%$ in humans [8]. When compared to tumors in other organs, primary bone tumors are uncommon, but its importance is due to difficulties in treatment, since they cause a broad spectrum of lesions [9]. 
Cell culture is the maintenance of the artificial form of cells in appropriate containers and packaging. Cell strains are subcultures of a primary culture that have been submitted to several subsequent cultures until the moment they become a monoclonal homogeneous cell population with well-established phenotypic and behavioral characteristics, unlike primary cultures that show a heterogeneous material of cell populations [10]. To isolate canine OS strains, Loukopoulos et al. (2004) [11] have established 120 subcultures or subsequent passages of the same primary culture.

Therapy studies involving in vitro models in oncology have used primary cultures rather than monoclonal neoplastic cell strains because the primary culture expresses reality closer to what actually occurs in patients affected by the disease, by presenting different neoplastic clones. For this reason, the primary culture becomes an excellent model for research in oncology [10].

Studies have shown that tumors exhibiting inflammatory processes related to the presence of Cox 2 play an important role in the development and progression of tumors in several species, including proliferation, cell transformation, growth, invasion and metastasis [12]. In this sense, some authors have suggested that COX-2 plays an important role in the genesis of canine osteossarcoma and it is associated with the most aggressive disease [5].

Epidemiological surveys in man and dog with spontaneous tumors have shown that non-selective Cox2 inhibitors have chemopreventive effects and antitumor activity on several types of cancers. Cox 2 is being tested with the aim of treating and preventing cancer. The use of selective Cox 2 inhibitors (coxibs) blocks the growth of many tumors through several mechanisms, mainly by anti-angiogenesis and pro-apoptotic effects. Preclinical findings have shown that the high Cox 2 expression observed in human tumors in advanced stages is the basis for a new anticancer therapy strategy based on a combination of selective Cox2 inhibitors and other treatment modalities [13]. According to Wolfesberger et al. (2006) [3], adjuvant administration of COX-2 inhibitor in vitro for canine osteosarcoma shows similar results to those found in other cancers (esophagus, colon, stomach and rectum), whose adjuvant treatments have shown encouraging results because they are associated to increased survival. Therefore, for cases in which it is expressed, COX-2 inhibitor therapies could be a good alternative.

Thus, this in vitro study exposed primary cells of five different canine osteosarcoma cultures to selective Cox2 inhibitor at different concentrations and times.

\section{Results and Discussion}

According to analysis of treatment with selective Cox 2 inhibitor in positive and negative spOS cultures

Table 1 and Figure 1 show the values expressed in

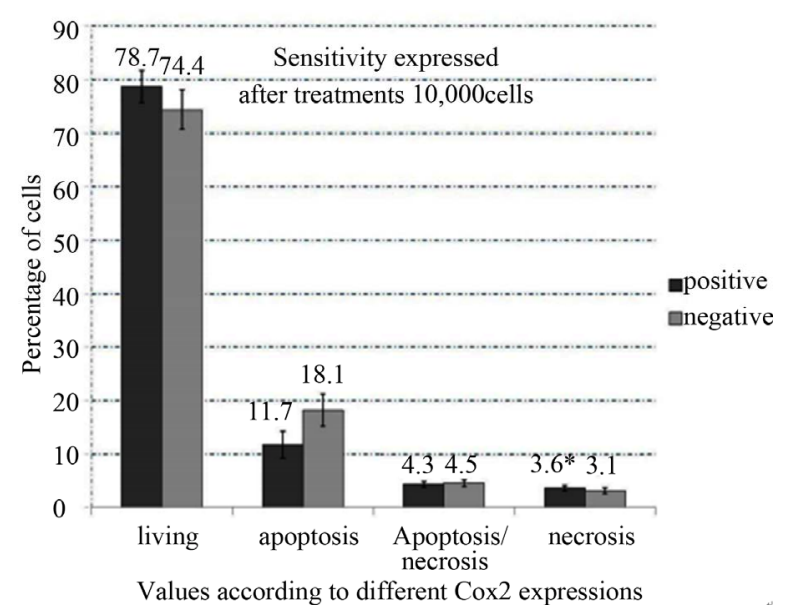

Figure 1. Percentages of living cells and apoptotic, apoptotic/necrotic and necrotic cells observed in the Cox 2 positive and negative groups. ${ }^{*} \mathrm{P} \leq \mathbf{0 . 0 5}$.

Table 1. Identification of living cells and apoptotic, apoptotic/necrotic and necrotic cells, according to the $\operatorname{Cox} 2$ expression.

\begin{tabular}{ccccc}
\hline Cox2 & Living & Apoptosis & Apoptosis necrosis & Necrosis \\
\hline Positive & $78.7 \pm 3.0$ & $11.7 \pm 2.5$ & $4.3 \pm 0.5$ & $3.6 \pm 0.5 \mathrm{a}$ \\
Negative & $74.4 \pm 3.7$ & $18.1 \pm 3.0$ & $4.5 \pm 0.6$ & $3.1 \pm 0.6 \mathrm{~b}$ \\
\hline
\end{tabular}

${ }^{a, b}$ Different superscript letters in the same column differ $(\mathrm{P} \leq 0.05)$. Positive and negative, according to the Cox 2 expression through immunohistochemistry.

positive cultures (spOS-2, spOS-4 and spOS-6) for value found with living cells $(78.7 \% \pm 3.0 \%)$, apoptotic $(11.7 \%$ $\pm 2.5 \%)$, apoptotics $/$ necrotic $(4.3 \% \pm 0.5 \%)$ and necrotic cells $(3.6 \% \pm 0.5 \%)$, and values in negative cultures (spOS-1 and spOS-3) for value found with living cells $(74.7 \% \pm 3.7 \%)$, apoptotic $(18.1 \% \pm 3.0 \%)$, apoptotic/ necrotic $(4.5 \% \pm 0.6)$ and necrotic cells $(3.1 \% \pm 0.6 \%)$.

According to Table 1 and Figure 1, it could also be observed that in negative cultures, although no differences have occurred, these cells seemed to be more sensitive to treatment, as seen for living cells $(78.7 \%$ positive $>744 \%$ negative), apoptotic ( $11.7 \%$ positive $<18.1 \%$ negative) and apoptotic/necrotic cells $(4.3 \%$ positive $<4.5 \%$ negative); however, for positive cultures, a higher $(\mathrm{P} \leq 0.05)$ number of necrotic cells ( $3.6 \%$ positive $>3.1 \%$ negative) was observed when compared with negative cultures.

According to analysis of treatment with selective Cox 2 inhibitor in function of times of $24 \mathrm{~h}, 48 \mathrm{~h}$ and $7 \mathrm{~h}$

It knows that to develop efficient therapies, the characterization of tumor sensitivity, demonstrated by apoptosis and necrosis increased rates plays a critical role in the selection of preferential treatments.

No difference $(\mathrm{P}>0.05)$ was found between the three times for living cells, apoptotic and apoptotic/necrotic cells in function of the exposure time with Celecoxib doses, as shown in Table 2 and Figure 2; however, there 


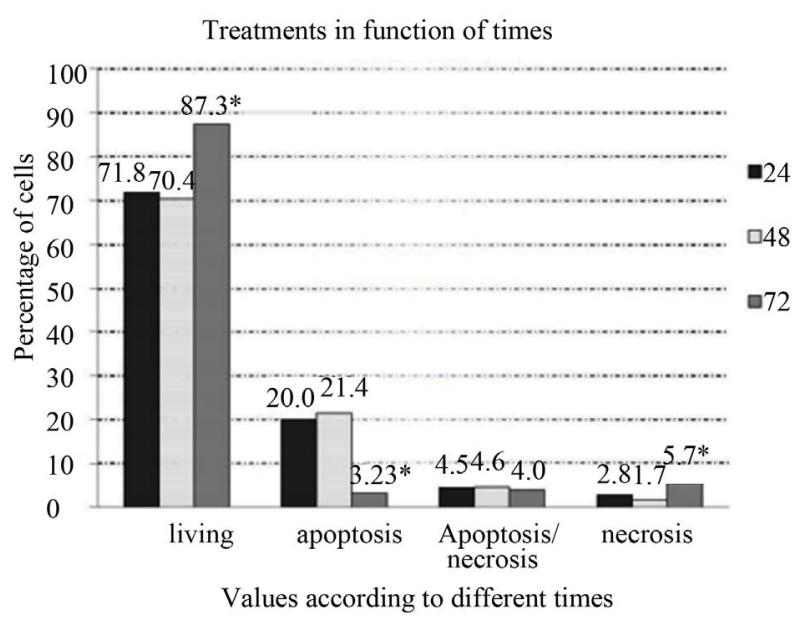

Figure 2. Percentages of living cells and apoptotic, apoptotic/ necrotic and necrotic cells observed in the groups of $24 \mathrm{~h}, 48$ $h$ and $72 \mathrm{~h}$ of celecoxib exposure. " $72 \mathrm{~h}$ differs $(\mathrm{P} \leq 0.05)$ from groups $24 \mathrm{~h}$ and $48 \mathrm{~h}$.

Table 2. Identification of living cells and apoptotic, apoptotic/necrotic and necrotic cells, according to the periods of $24 \mathrm{~h}, 48 \mathrm{~h}$ and $72 \mathrm{~h}$.

\begin{tabular}{ccccc}
\hline Period-hours & Living & Apoptosis & $\begin{array}{c}\text { Apoptosis } \\
\text { necrosis }\end{array}$ & Necrosis \\
\hline 24 & $71.8 \pm 4.1^{\mathrm{a}}$ & $20.0 \pm 3.4^{\mathrm{a}}$ & $4.5 \pm 0.6$ & $2.8 \pm 0.7^{\mathrm{a}}$ \\
48 & $70.4 \pm 4.1^{\mathrm{a}}$ & $21.4 \pm 3.4^{\mathrm{a}}$ & $4.6 \pm 0.6$ & $1.7 \pm 0.7^{\mathrm{a}}$ \\
72 & $87.3 \pm 4.1^{\mathrm{b}}$ & $3.23 \pm 3.4^{\mathrm{b}}$ & $4.0 \pm 0.6$ & $5.7 \pm 0.7^{\mathrm{b}}$ \\
\hline
\end{tabular}

${ }^{a, b}$ Different superscript letters in the same column differ $(\mathrm{P} \leq 0.05)$.

are similarities in the values for times of $24 \mathrm{~h}$ and $48 \mathrm{~h}$, with a slight reduction of living cells, increasing in the same way apoptotic and apoptotic/necrotic cells. SinghRanger et al., 2008 [14] shown that when Cox2 is expressed, Bcl-2, an anti-apoptotic protein, is also expressed and vice versa. Moreover, overexpression of COX-2 has been implicated in the development of several cancers, since COX-2 inhibits apoptosis and increases invasiveness of malignant cells [15]. The most abundant PG produced by COX-2 is PGE2 [16]. PGE2 binds to four subtypes of receptors (EP1-EP4), promoting tumor growth by stimulating cell proliferation, promoting angiogenesis, inhibiting apoptosis, inducing invasion, and suppressing immune activation. Thus, COX-2 inhibitor could act preventing the production of PGE2 and stimulating apoptosis [17].

However, significance was observed for the values of necrotic cells as shown in columns with different letters ( $P$ $\leq 0.05$ ). Thus, the phenomenon of necrosis at $24 \mathrm{~h}$ and 48 $\mathrm{h}$, values were $2.8 \%$ and $1.7 \%$, without statistical significance $(\mathrm{P}>0.05)$; however, for time of $72 \mathrm{~h}$ with value of $5.7 \%$, difference between the other two previous values was observed $(\mathrm{P} \leq 0.05)$. For the time of 72 hours, a significant increase $(\mathrm{P} \leq 0.05)$ was observed in the number of living cells $(87.3 \%)$ in relation to previous times of $24 \mathrm{~h}$ (71.8\%) and $48 \mathrm{~h}(70.4 \%)$, being also found a large decrease of apoptotic cells $(\mathrm{P} \leq 0.05)$, shown for $24 \mathrm{~h}(20.0 \%)$ and $48 \mathrm{~h}(21.4 \%)$, a decrease for $72 \mathrm{~h}(3.23 \%)$, which was also observed for necrotic cells, whose value increased significantly $(\mathrm{P} \leq 0.05)$. However, there was no difference $(P>0.05)$ between the three times for the percentages of apoptotic/necrotic cells.

A likely explanation for the sudden increase of living cells and decreased number of apoptotic cells is the artificial selection that Celecoxib provided to cells in the different cultures; therefore, those resistant to different Celecoxib concentrations divided as usual, causing increased number of living cells and reduced number of apoptotic cells.

The significant number $(\mathrm{P} \leq 0.05)$ of necrotic cells (5.7\%) compared to the other two previous values is due to the fact that the longest exposure time $(72 \mathrm{~h})$ and highest concentrations of the selective Cox 2 inhibitor provided lower cellular stability, higher signaling for apoptosis in the first moment, whose cells already underwent necrosis, thus they would be counted in the total percentages of treatments with different Celecoxib doses, which is consistent with Gupta et al. (2004) [18], Fantappie et al. (2007) [19] and Huang and Sinicrope, (2010) [20].

According to Gupta et al. (2004) [18], Arico et al., (2002) [21] and Huang and Sinicrope, (2010) [20], Celecoxib has great ability to promote apoptosis and necrosis of tumor cells occurs as a side effect, a fact which corroborates our study, in which with increasing concentrations and time of $72 \mathrm{~h}$, a greater the number of necrotic cells was found.

According to analysis of different concentrations in treatments with selective Cox2 inhibitor

According to values shown in Table $\mathbf{3}$ and Figure 3,

Celecoxib response dose profile

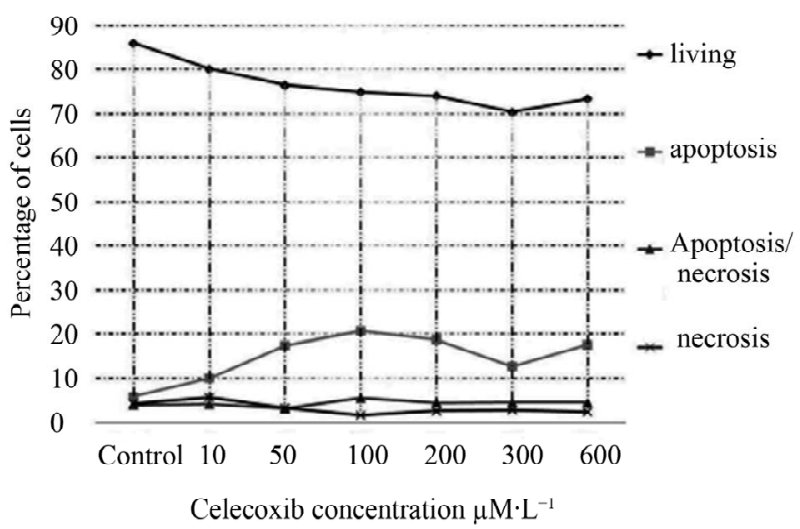

Figure 3. Percentages of living cells and apoptotic, apoptotic/ necrotic and necrotic cells observed in the groups. 
Table 3. Identification of living cells and apoptotic, apoptotic/necrotic and necrotic cells according to increasing celecoxib concentrations.

\begin{tabular}{ccccc}
\hline $\begin{array}{c}\text { Celecoxib } \\
\left(\boldsymbol{\mu M} \cdot \mathbf{L}^{-1}\right)\end{array}$ & Living & Apoptosis & $\begin{array}{c}\text { Apoptosis } \\
\text { necrosis }\end{array}$ & Necrosis \\
\hline Control & $86.0 \pm 6.3$ & $6.0 \pm 5.1$ & $4.0 \pm 1.0$ & $4.4 \pm 1.1$ \\
$\mathbf{1 0}$ & $80.1 \pm 6.3$ & $10.2 \pm 5.1$ & $4.2 \pm 1.0$ & $5.8 \pm 1.1$ \\
$\mathbf{5 0}$ & $76.5 \pm 6.3$ & $17.6 \pm 5.1$ & $3.2 \pm 1.0$ & $3.4 \pm 1.1$ \\
$\mathbf{1 0 0}$ & $75.0 \pm 6.3$ & $20.8 \pm 5.1$ & $5.6 \pm 1.0$ & $1.7 \pm 1.1$ \\
$\mathbf{2 0 0}$ & $74.1 \pm 6.3$ & $18.9 \pm 5.1$ & $4.5 \pm 1.0$ & $2.7 \pm 1.1$ \\
$\mathbf{3 0 0}$ & $70.5 \pm 6.3$ & $12.9 \pm 5.1$ & $4.6 \pm 1.0$ & $2.9 \pm 1.1$ \\
$\mathbf{6 0 0}$ & $73.5 \pm 6.3$ & $17.8 \pm 5.1$ & $4.6 \pm 1.0$ & $2.5 \pm 1.1$ \\
\hline
\end{tabular}

There was no significant difference $(\mathrm{P}>0.05)$.

although there were no differences $(\mathrm{P} \leq 0.05)$ for living cells, apoptotic and apoptotic/necrotic cells, there is a slight reduction in the values of living cells and slight increase in the number of apoptotic cells. Thus, there was a trend for reducing the number of living cells and increasing the number of apoptotic cells. It was also identified that the concentration of $100 \mu \mathrm{M} \cdot \mathrm{L}^{-1}$ numerically produced the largest signaling for apoptosis $(20.8 \%)$ and the smallest $(\mathrm{P}=0.08)$ for necrosis $(1.7 \%)$, and this point can be identified as the onset of the pharmacodynamic phenomenon.

However, from this concentration on, there was a decrease in values of living cells and increase in the number of necrotic cells. In addition, there was a trend $(P=0.08)$ in reducing the percentage of necrotic cells for group of $100 \mu \mathrm{M} \cdot \mathrm{L}^{-1}$ when compared to the group of $10 \mu \mathrm{M} \cdot \mathrm{L}^{-1}$.

\section{Conclusion}

Comparing Cox 2 positive and Cox 2 negative cultures, it could be inferred that there was difference in cell necrosis, in which Cox 2 positive cultures were greater than Cox 2 negative cultures and there was no difference between Cox 2 positive and Cox 2 negative cultures for the percentage of living cells and apoptotic and apoptotic/necrotic cells. Groups of $72 \mathrm{~h}$ showed higher percentage of living cells, lower percentage of apoptotic cells and higher percentage of necrotic cells in relation to groups of 24 and 48 hours. It was also observed that there was no difference between apoptotic/necrotic groups for $24 \mathrm{~h}, 48 \mathrm{~h}$ and $72 \mathrm{~h}$. There was a trend in reducing the percentage of necrotic cells for groups of $100 \mu \mathrm{M} \cdot \mathrm{L}^{-1}$ when compared to groups of $10 \mu \mathrm{M} \cdot \mathrm{L}^{-1}$, and there was no difference between the percentage of Celecoxib concentrations with the percentage of living cells and apoptotic and apoptotic/necrotic cells.

\section{Methods}

Ethical aspects and origin of the material under study. This study used primary cultures of canine osteosarcoma that were previously isolated and established by means of a panel of target biomarkers. Cell cultures were obtained in the routine of the Veterinary Hospital and FMVZ Veterinary Pathology Service-UNESP Campus of Botucatu, Brazil. All dog owners were informed about the study procedures, allowing the publication of data obtained in this study by signing the Free and Informed Consent Form. The study was approved by the FMVZ Ethics Committee-UNESP, Campus of Botucatu, protocol number 98/ 2008.

\section{1. spOS Primary Cultures}

This study used five spOS primary cultures isolated and characterized by means of biomarker panel such as the biochemical panel by alizarin red and by target proteins such as vimentin, cytokeratin, osteocalcin, osteopontin, osterix, cyclo-oxygenase-2. Values were determined by means of flow cytometry.

The canine osteosarcoma cell cultures were classified according cyclooxygenase- 2 expression in tumor tissue fragments and cells after cultivation by flow citometry and immunohistochemistry. Negative cultures were identified as negative by immunohistochemistry and low intensity ( $<1 \%$ of cells expressed COX-2) by flow cytometry. Positive cultures were labeled for COX-2 by immunohistochemistry and demonstrated expression equal or greater than $1 \%$ of cells by flow citometry.

\subsection{Cell Culture and Treatments}

The following factorial arrangement was created from spOS primary cultures: 2 (positive, negative), $\times 7$ (control, $10,50,100,200,300$ and $600 \mu \mathrm{M} \cdot \mathrm{L}^{-1}$ Celecoxib $) \times 3(24$, 48 and $72 \mathrm{~h}$ ) with relative percentage of living cells and apoptotic, apoptotic-necrotic and necrotic cells. Thus, each cell culture was trypsinised in separate (TrypLE Select Invitrogen 12563-029), and counted with the aid of a Neubauer chamber and cultured in three $75 \mathrm{~cm}^{2}$ flasks with $5 \times 10^{6}$ cells per flask, which were used for treatment times of $24 \mathrm{~h}, 48 \mathrm{~h}$ and $72 \mathrm{~h}$, respectively. For the beginning of treatments, cell cultures reached maximum at the 8th passage. After 10 days of culture with confluence over $90 \%$, each flask was individually trypsinized, and the cells were counted with the aid of a Neubauer chamber and cultured in seven $25 \mathrm{~cm}^{2}$ flasks containing 106 cells per flask, with $5 \mathrm{ml}$ of DMEM high glucose medium supplemented with $10 \%$ FCS, added of a combination of Penicillin $(100 \mathrm{U} / \mathrm{ml})$ with streptomycin $(100 \mathrm{mg} / \mathrm{ml})$ and amphotericin-B $(3 \mu \mathrm{g} / \mathrm{mL})$. After 24 hours, the treatments were initiated, and their culture media were replaced by others at the same concentrations of Fetal Calf Serum, 
Penicillin, Streptomycin and Amphotericin, but with the addition of increasing concentrations (control, 10, 50, 100, 200,300 and $600 \mu \mathrm{M} \cdot \mathrm{L}^{-1}$ ) of selective Cox 2 inhibitor (celecoxib).

The flasks were identified, packed and kept in incubator at $5 \% \mathrm{CO}_{2}, 95 \%$ moisture and temperature of $37.5^{\circ} \mathrm{C}$ for $24 \mathrm{~h}, 48 \mathrm{~h}$ and $72 \mathrm{~h}$.

\subsection{Flow Cytometry}

For the reading of Celecoxib-treated cells through flow cytometry, the entire culture medium was discarded in 15 $\mathrm{mL}$ tubes previously identified, being washed twice with PBS pH 7.2. Then, the cells were trypsinised, and the flask content (cell suspension with trypsin) was added in the respective $15 \mathrm{~mL}$ tubes initially identified with the culture media containing the treatments. Thus, it was possible to analyze all content present in the flask.

Subsequently, these tubes were centrifuged for 10 minutes at 2000 RPM. The supernatant was discarded, and the pellet was resuspended with $200 \mu \mathrm{L}$ PBS pH 7.4 and added of $\mathrm{Ca}^{2+}$ and $\mathrm{Cl}^{-}$and then this content was divided into two plastic tubes for cytometer (BD TM), each tube containing $100 \mu \mathrm{L}$ of PBS solution $\mathrm{pH} 7.4$ added of $\mathrm{Ca}^{2+}$ and $\mathrm{Cl}^{-}$and treated cells.

One of the tubes was used as negative control, i.e., no substance was added after this procedure. The other tube was added of $5 \mu \mathrm{L}$ of Annexin V (A13201-combined with Alexa Fluor 488-Invitrogen) and left to rest for $30 \mathrm{~min}$. Soon after, $1 \mu \mathrm{L}$ of Propidium Iodide was added and the sample was homogenized. After $10 \mathrm{~min}$, all tubes were transferred to reading in the flow cytometer FACS Calibur BD TM, from the Blood Center of the Faculty of Medicine at Botucatu, UNESP, SP, Brazil.

In this reading, the dot plot system identified living cells, apoptotic cells and necrotic cells and those with double reading. The flow cytometry results were based on a sample of 10,000 cells and were expressed in percentages.

\subsection{Statistical Analysis}

The binomial dependent variables (percentage of living cells and apoptotic, apoptotic/necrotic, and necrotic cells) were evaluated using ANOVA followed by Tukey's test using PROC GLM of SAS (SAS Inst. Inc., Cary, NC, USA). Sources of variation in the model, including Cox 2 positivity (more or less explicit) treatment (Control, 10, $50,100,200,300$ and $600 \mathrm{mM}$ of Celecoxib), exposure time to Celecoxib (24, 48 and $72 \mathrm{~h}$ ) and first-order interactions; all effects were considered fixed effects. Data expressed in percentages not submitted to the normality test (Shapiro-Wilk, Kolmogorov-Smirnov and Cramervon Mises), were submitted to arcsine transformation.

The main effects are presented in the absence of sig- nificant interaction. The results are presented as mean of least squares and standard error. For all tests, significance level of $5 \%$ was adopted $(\mathrm{P}<0.05)$.

\section{Authors' Contributions}

PROB: contributed substantially to the conception, design of the study and sampling, being involved in the elaboration of the manuscript, tables, charts and critical review of the intellectual content. MTSA: substantial importance in the experimental design, coordination, interpretation of results and critical review of the manuscript. MFMRG: played an important role in the design and review of the manuscript. JFLN: participated in the standardization and development of experimental studies. FCL: provided the laboratory for the development of in vitro studies and contribution to the standardization of techniques. NSR: conceived the study, participated in its design and coordination, and helped writing the manuscript. All authors read and approved the final manuscript.

\section{Acknowledgements and Funding}

We acknowledge FAPESP (2009/53493-9) and (2009/ 53777-7) for the financial support and Mati Kiupel for substantial importance in the experimental design.

\section{REFERENCES}

[1] R. C. Straw, S. J. Withrow and B. E. Powers, "Management of Canine Appendicular Osteosarcoma," Veterinary Clinics of North America-Small Animal Practice, Vol. 20, No. 4, 1990, pp. 1141-1161.

[2] A. S. Hammer, F. R. Weeren and S. L. Padgett, "Prognostic Factors in Dogs with Osteosarcomas of the Flat or Irregular Bones," Journal of the American Animal Hospital Association, Vol. 31, No. 4, 1995, pp. 321-326.

[3] B. Wolfesberger, I. Walter, C. Hoelzl, J. G. Thalhamammer and M. Egerbacher, "Antioplasttic Effect of the Cyclooxygenase Inhibitor Meloxicam on Canine Osteosarcoma Cells," Research in Veterinary Science, Vol. 80, No. 3, 2006, pp. 308-316.

http://dx.doi.org/10.1016/j.rvsc.2005.07.013

[4] J. Kirpensteijn, E. P. M. Timmermans-sprang, E. V. Garderen, G. R. Rutteman, I. S. L-V. Leeuwen and J. A. Mol, "Growth Hormone 109 Gene Expression in Canine Normal Growth Plates and Spontaneous Osteosarcoma," Molecular and Celular Endocrinology, Vol. 197, 2002, pp. 179-185.

[5] M. N. Mullins, S. E. Lana, W. S. Dernell, G. K. Ogilvie, S. J. Withrow and E. J. Ehrhant, "Ciclooxygenase-2 Expression in Canine Appendicular Osteosarcomas," Journal of Veterinary Internal Medicine, Vol. 18, No. 6, 2004, pp. 859-865. http://dx.doi.org/10.1111/j.1939-1676.2004.tb02633.x

[6] C. Khanna, J. Khan, P. Nguyen, J. Prehn, J. Caylor, C. Yeung, J. Trepel, P. Meltzer and L. Helman, "Metastasis- 
Associated Differences in Gene Expression in a Murine Model of Osteosarcoma," Cancer Research, Vol. 61, No. 9, 2001, pp. 3750-3759.

[7] W. S. Dernell, N. P. Ehrhart, R. C. Straw and D. M. Vail, "Tumor of the Skeletal System," In: S. J. Withrow and D. M. Vail, Small Animal Clinical Oncology, 4th Edition, 2007, pp. 540-582.

[8] R. Gorlick and C. Khanna, "Osteosarcoma," Journal of Bone and Mineral Research, Vol. 25, No. 4, 2010, pp. 683-691. http://dx.doi.org/10.1002/jbmr.77

[9] G. Brasileiro Filho, "Sistema Ósteo-Articular," In: "Bogliolo Patologia," 7th Edition, Guanabara Koogan, Rio de Janeiro, 2006, pp. 979-1035.

[10] R. I. Freshney, "Culture of Animals Cells," 6th Edition, John Wiley \& Sons, Inc., New Jersey, 2010, p. 732. http://dx.doi.org/10.1002/9780470649367

[11] P. Loukopoulos, T. O’brien, M. Ghoddusi, B. A. Mungall and W. F. Robinson, "Characterisation of Novel Canine Osteosarcoma Cell Lines Producing High Levels of Matrix Metalloproteinases," Research in Veterinary Science, Vol. 77, No. 2, 2004, pp. 131-141. http://dx.doi.org/10.1016/j.rvsc.2004.01.006

[12] G. Finak, N. Bertos, F. Pepin, S. Sadekova, M. Souleimanova, H. Zhao, H. Chen, G. Omeroglu, S. Meterissian, A. G. Meroglu, M. Hallett and M. Park, "Stromal Gene Expression Predicts Clinical Outcome in Breast Cancer," Nature Medicine, Vol. 14, 2008, pp. 518-527. http://dx.doi.org/10.1038/nm1764

[13] G. Gasparini, R. Longo, R. Sarmiento and A. Morabito, "Inhibitors of Cyclo-Oxigenase 2: A New Class of Anticancer Agents?" The Lancet Oncology, Vol. 4, No. 10, 2003, pp. 605-615.

http://dx.doi.org/10.1016/S1470-2045(03)01220-8

[14] G. Singh-Ranger, M. Salhab and K. Mokbel, "The Role of Cyclooxygenase-2 in Breast Cancer: Review," Breast Cancer Res. Treat, Vol. 109, No. 2, 2008, pp. 189-198. http://dx.doi.org/10.1007/s10549-007-9641-5

[15] C. Waskewich, R. D. Blumenthal, H. Li, R. Sein, D. M.
Goldenberg and J. Burton, "Celecoxib Exhibits the Greatest Potency Amongst Cyclooxygenase (COX) Inhibitors for Growth Inhibition of COX-2-Negative Hematopoietic and Epithelial Cell Lines," Cancer Research, Vol. 62, No. 7, 2002, pp. 2029-2033.

[16] S. I. Mohammed, K. N. M. Khan, R. S. Sellers, M. G. Hayek, D. B. Denicola, L. Wu, P. L. Bonney and D. W. Knapp, "Expression of Cyclooxygenase-1 and 2 Naturally-Occuring Canine Cancer," Prostaglandins Leukotrienes and Essential Fatty Acids, Vol. 70, No. 5, 2004, pp. 479-483. http://dx.doi.org/10.1016/j.plefa.2003.10.002

[17] D. Wang and R. N. Dubois, "Prostaglandins and Cancer," An International Journal of Gastroenterology and Hepatology, Vol. 55, No. 1, 2006, pp. 115-122.

[18] S. Gupta, V. M. Adhami, M. Subbarayan, G. T. Maclennan, J. S. Lewin, U. O. Hafeli, P. Fu and H. Mukhtar, "Suppression of Prostate Carcinogenesis by Dietary Supplementation of Celecoxib in Transgenic Adenocarcinoma of the Mouse Prostate Model," Cancer Research, Vol. 64, No. 9, 2004, pp. 3334-3343.

http://dx.doi.org/10.1158/0008-5472.CAN-03-2422

[19] O. Fantappiè, M. Solazzo, N. Lasagna, F. Platini, L. Tessitore and R. Mazzanti, "P-Glycoprotein Mediates Celecoxib-Induced Apoptosis in Multiple Drug-Resistant Cell Lines," Cancer Research, Vol. 67, No. 10, 2007, pp. 4915-4923. http://dx.doi.org/10.1158/0008-5472.CAN-06-3952

[20] S. Huang and F. A. Sinicrope, "Celecoxib-Induced Apoptosis Is Enhanced by ABT-737 and by Inhibition of Autophagy in Human Colorectal Cancer Cells," Autophagy, Vol. 6, No. 2, 2010, pp. 256-269. http://dx.doi.org/10.4161/auto.6.2.11124

[21] S. Arico, S. Pattingre, C. Bauvy, P. Gane, A. Barbat, P. Codogno and E. Ogier-denis, "Celecoxib Induces Apoptosis by Inhibiting 3-Phosphoinositide-Dependent Protein Kinase-1 Activity in the Human Colon Cancer HT-29 Cell Line," The Journal of Biological Chemistry, Vol. 277, No. 31, 2002, pp. 27613-27621. http://dx.doi.org/10.1074/jbc.M201119200

\section{List of Abbreviations}

OS: Osteosarcoma

spOS: São Paulo-Osteosarcoma

Cox2: cyclo-oxygenase-2 